
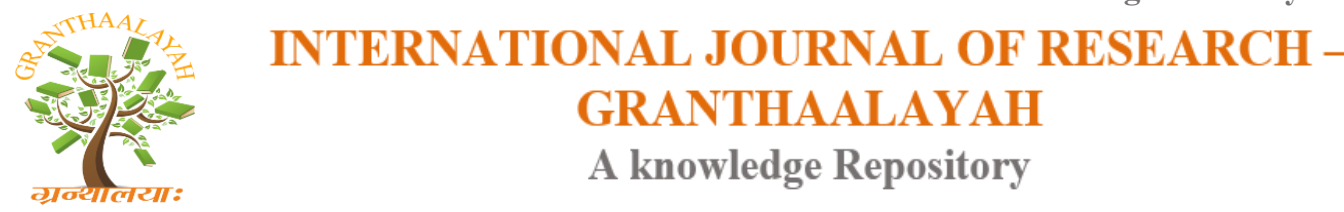

Social

\title{
PERCEPTION ON HANDWRITING AMONG SECONDARY SCHOOL STUDENTS
}

\author{
Dr. M. Leonard Ashok ${ }^{* 1}$, Ms. S.Saumya ${ }^{2}$ \\ ${ }^{* 1}$ Principal, CMS College of Education, Ganapathy Coimbatore, Tamilnadu - 641006, INDIA \\ ${ }^{2}$ Special Educator, Air force School, Sulur, Coimbatore, Tamilnadu - 641402, INDIA
}

\begin{abstract}
Good handwriting serves as a primary tool of communication and knowledge assessment for students in classroom. Though computer and e- mail play an important role in our lives, nothing will ever replace the sincerity and individualism expressed through handwritten words. Our education system stress on student's handwriting at primary level by introducing books like cursive writing, ruled notes and handwritten works. But as they upgrade, impact on handwriting slowly vanishes among students mainly at secondary level where they are stressed and deviated towards rote learning as a medium to fetch marks. But at this point we forget that only an aesthetic handwriting is a vehicle to impress and deliver our thoughts in the mind of evaluator, particularly when the evaluator is a stranger in case of public exams. This article is an attempt to find out the perception on handwriting among ninth standard school students and its influence on their academic achievement. This study has revealed that there is an impact of handwriting on academic achievement. Thereby it is stressed that handwriting should be given equal importance while teachers prepare their students for academic achievement.
\end{abstract}

Keywords:

handwriting, students, education system, academic achievement.

Cite This Article: Dr. M. Leonard Ashok, and Ms. S.Saumya, "PERCEPTION ON HANDWRITING AMONG SECONDARY SCHOOL STUDENTS" International Journal of Research - Granthaalayah, Vol. 4, No. 5: SE (2016): 1-6.

\section{INTRODUCTION}

There is a link between handwriting and brain development which shows that sequential hand movements used in handwriting activate the regions of the brain associated with thinking, shortterm memory and language. Poor handwriting shows serious consequences on early literacy and academic performance. Children who experience difficulty mastering this handwriting skill may avoid writing and decide that they cannot write, leading to arrested writing development .Handwriting is critical to the production of creative and well-written text affecting both fluency and the quality of the composition. Illegible handwriting also has secondary effects on school 
achievement and self-esteem. In a technology-centered world, handwritten letters and notes are becoming less and less common as people grow accustomed to typing on laptops or text messaging on cell phones. Legible handwriting is an important skill - far too important to be left to chance. Systematic handwriting instruction can and should be provided in every school and classroom because all children deserve the benefits that legible handwriting can confer. If handwriting has a poor appearance, the writer is judged poorly by our society. Failure to attain handwriting competency during the school-age years often has far-reaching negative effects on both academic success and self-esteem.

Hand writing has its impact on all the areas of education but in today's scenario it is losing its importance among students because of unattended stress on handwriting by teacher and parents and blooming of modern technology. If hand writing has to do just by writing a sentence, this topic won't be an attention seeking but hand writing has its influence on memory, character, personality, perception, etc. Today our education system is focusing more on theoretical curriculum which is leaving no room for hand writing improvement among students. Education problems are now nowhere treated with graphology which is highlighted in remedial classes where students are forced on rote learning.

\section{OBJECTIVES}

1. To find out the perception on handwriting among secondary level students.

2. To find out the impact of personal variables like sex, location of school on perception on handwriting among secondary school students.

\section{HYPOTHESES}

1. There is no significant difference in perception on handwriting among secondary school students.

2. There is no significant difference between male and female secondary school students in perception on handwriting.

3. There is no significant difference between urban and rural secondary school students in perception on handwriting.

\section{RESEARCH DESIGN}

In view of nature of the problem, descriptive survey method is adopted.

\section{RESEARCH TOOL}

To assess the perception on handwriting, a questionnaire consisting 48 items was constructed. The marks of the previous examination were taken for assessing their academic achievement.

\section{SAMPLE}

300 school students of Coimbatore studying $9^{\text {th }}$ standard were taken as sample using simple random sampling technique. 


\section{RESULTS AND DISCUSSION}

Teachers while preparing their students for exams focus on how to read \& learn but not on how to write or present without knowing that if the matter has to reach a second person it needs proper presentation of object. Earlier the only mean to hire a person for job was through his handwriting analysis because it directly reflects once personality in total for a strange boss. But now only rote knowledge is assessed through objective type questions and may be this is the reason that most of the organization fail in their motive.

An answer sheet with soothing hand writing acts as a candle which glows evaluator heart. Evaluator reads personality of a student through his or her hand writing, it shows how confident was the student while writing the exam which directly indicates ones deep knowledge and preparation of exam. Teachers should be confident to adopt hand writing as remedial measure to attain academic excellence. Worst part is that when students reach secondary level in spite of being strong theoretical knowledge cannot represent them as they expect because of the difficulty they face in presenting their knowledge, proper time management as a result of lack of writing practice, vocabulary problem, underdeveloped motor skills etc., Extent of impact handwriting showers on academic achievement can be transparently studied during public exam evaluation when both evaluator and student are strange to each other. In this case only handwriting forms a base for an evaluator to judge a student.

\section{Hypothesis - 1}

There is no significant difference in perception on handwriting among secondary school students.

Table 1: Levels of perception on handwriting among $9^{\text {th }}$ standard students

\begin{tabular}{|c|c|c|c|c|c|c|c|c|c|c|c|}
\hline \multirow[t]{2}{*}{ S.no } & \multirow{2}{*}{$\begin{array}{l}\text { Name of the } \\
\text { factors }\end{array}$} & \multicolumn{3}{|l|}{ Low } & \multicolumn{3}{|c|}{ Moderate } & \multicolumn{3}{|c|}{ High } & \multirow[t]{2}{*}{ Total } \\
\hline & & Q1 & $\mathbf{F}$ & $\%$ & $\mathbf{Q 2}$ & $\mathbf{F}$ & $\%$ & Q3 & $\mathbf{F}$ & $\%$ & \\
\hline 1. & $\begin{array}{l}\text { Learning } \\
\text { Environment }\end{array}$ & 27 & 78 & 26 & 31 & 151 & 50.3 & 35 & 71 & 23.6 & 300 \\
\hline 2. & Hobby of Writing & 29 & 78 & 26 & 34 & 148 & 49.3 & 38 & 74 & 24.6 & 300 \\
\hline 3. & $\begin{array}{l}\text { Academic } \\
\text { Structure }\end{array}$ & 44 & 81 & 27 & 49 & 152 & 50.6 & 54 & 67 & 22.3 & 300 \\
\hline 4. & $\begin{array}{l}\text { Attitude Towards } \\
\text { Handwriting }\end{array}$ & 44.25 & 75 & 25 & 50 & 153 & 51 & 55 & 72 & 24 & 300 \\
\hline Total & & 26 & 85 & 25 & 45 & 158 & 50 & 36 & 78 & 25 & 300 \\
\hline
\end{tabular}

The result given in table 1 shows the quartiles and frequency level of perception on handwriting among 9th standard students. According to the table $26 \%$ of students have low level, 50.3\% have moderate level and $23.6 \%$ have high level of perception on handwriting with respect to the factor learning environment. Based on the factor hobby of writing $26 \%$ of students have low level, $49.3 \%$ have moderate level, and $24.6 \%$ have high level of perception on handwriting. With respect to the factor academic structure $27 \%$ of students have low level, $50.6 \%$ have moderate 
level, and $22.35 \%$ have high level of perception on handwriting. Based on the factor attitude towards handwriting $25 \%$ of students belong to low level, $51 \%$ belong to moderate level, $24 \%$ have high level of perception on handwriting. Among the four factors, moderate percentage of students show high level of perception on handwriting. When the overall level of perception on handwriting is considered, $25 \%$ belong to low level, $50 \%$ belong to moderate level and $25 \%$ belong to high level. Hence it is concluded that there is a significant difference in perception on handwriting among secondary school students.

\section{Hypothesis-2}

There is no significant difference between male and female secondary school students in perception on handwriting.

Table 2: Mean score difference in perception on handwriting Based on their sex among 9 th standard students.

\begin{tabular}{|c|c|c|c|c|c|c|c|}
\hline S.no & Name of the factor & Sex & $\mathbf{N}$ & Mean & SD & $\begin{array}{l}\text { t- } \\
\text { value }\end{array}$ & $\begin{array}{l}\text { Significance } \\
\text { at } 0.05 \text { level }\end{array}$ \\
\hline \multirow[t]{2}{*}{1.} & \multirow{2}{*}{$\begin{array}{l}\text { Learning } \\
\text { Environment }\end{array}$} & Male & 134 & 29.85 & 4.914 & \multirow[t]{2}{*}{3.222} & \multirow[b]{2}{*}{$\mathrm{S}$} \\
\hline & & Female & 166 & 31.91 & 5.935 & & \\
\hline \multirow[t]{2}{*}{2.} & \multirow[t]{2}{*}{ Hobby Of Writitng } & Male & 134 & 32.99 & 6.323 & \multirow[t]{2}{*}{2.303} & \multirow[b]{2}{*}{$\mathrm{S}$} \\
\hline & & Female & 166 & 34.75 & 6.743 & & \\
\hline \multirow[t]{2}{*}{3.} & \multirow[t]{2}{*}{ Academic Structure } & Male & 134 & 47.63 & 7.043 & \multirow[t]{2}{*}{1.992} & \multirow{2}{*}{$\mathrm{S}$} \\
\hline & & Female & 166 & 49.34 & 7.712 & & \\
\hline \multirow[t]{2}{*}{4.} & \multirow{2}{*}{$\begin{array}{l}\text { Attitude Towards } \\
\text { Handwriting }\end{array}$} & Male & 134 & 49.18 & 7.327 & \multirow[t]{2}{*}{1.762} & \multirow{2}{*}{ NS } \\
\hline & & Female & 166 & 50.67 & 7.295 & & \\
\hline \multirow{2}{*}{\multicolumn{2}{|c|}{ Total }} & Male & 134 & 159.65 & 18.648 & \multirow[t]{2}{*}{3.055} & \multirow[t]{2}{*}{$\mathrm{S}$} \\
\hline & & Female & 166 & 166.67 & 20.686 & & \\
\hline
\end{tabular}

The result provided in table 2 shows that the $t$ value is statistically significant at 0.05 level for all factors except one factor attitude towards handwriting. Hence the hypothesis is rejected and it is concluded that there is significant difference between male and female secondary school students in perception on handwriting.

\section{Hypothesis-3}

There is no significant difference between urban and rural secondary school students in perception on handwriting.

Table 3: Mean score difference in perception on handwriting based on locality of school among $9^{\text {th }}$ standard students

\begin{tabular}{|l|l|l|l|l|l|l|l|}
\hline S.no & $\begin{array}{l}\text { Name of the } \\
\text { factor }\end{array}$ & Locality & $\mathbf{N}$ & Mean & SD & $\begin{array}{l}\text { t } \\
\text { value }\end{array}$ & $\begin{array}{l}\text { Significance } \\
\text { at 0.05 level }\end{array}$ \\
\hline & Learning & Urban & 155 & 31.12 & 5.761 & .404 & NS \\
\hline
\end{tabular}




\begin{tabular}{|c|c|c|c|c|c|c|c|}
\hline 1. & Environment & Rural & 145 & 30.86 & 5.413 & & \\
\hline \multirow[b]{2}{*}{2.} & \multirow[t]{2}{*}{ Hobby Of Writing } & Urban & 155 & 34.61 & 6.831 & \multirow[t]{2}{*}{1.749} & \multirow[t]{2}{*}{ NS } \\
\hline & & Rural & 145 & 33.28 & 6.306 & & \\
\hline \multirow[b]{2}{*}{3.} & \multirow{2}{*}{$\begin{array}{l}\text { Academic } \\
\text { Structure }\end{array}$} & Urban & 155 & 49.07 & 8.439 & \multirow[t]{2}{*}{1.188} & \multirow[t]{2}{*}{ NS } \\
\hline & & Rural & 145 & 48.05 & 6.228 & & \\
\hline \multirow[b]{2}{*}{4.} & \multirow{2}{*}{$\begin{array}{l}\text { Attitude Towards } \\
\text { Handwriting }\end{array}$} & Urban & 155 & 49.25 & 7.590 & \multirow[t]{2}{*}{1.867} & \multirow[t]{2}{*}{ NS } \\
\hline & & Rural & 145 & 50.82 & 6.987 & & \\
\hline \multirow{2}{*}{\multicolumn{2}{|c|}{ TOTAL }} & Urban & 155 & 164.04 & 21.709 & \multirow[t]{2}{*}{.447} & \multirow[t]{2}{*}{$\mathrm{NS}$} \\
\hline & & Rural & 145 & 163.00 & 18.231 & & \\
\hline
\end{tabular}

The result given in table 3 shows that $t$ value is statistically non-significant at 0.05 level for all factor. Hence the hypothesis is accepted and it is concluded that there is no significant difference between urban and rural secondary school students in perception on handwriting.

\section{SUMMARY OF FINDINGS}

The major findings of the study are

1. There is significant difference in perception on handwriting among secondary students.

2. There is significant difference between male and female secondary school students in perception on handwriting.

3. There is no significant difference between urban and rural secondary school students in perception on handwriting.

\section{EDUCATIONAL IMPLICATION}

This study revealed that perception on handwriting has its impact on academic achievement. Aesthetic handwriting acts as a candle which glows evaluators mind. So teachers should take keen interest to develop aesthetic handwriting among students while preparing them for academics which will aid them to be an achiever.

To achieve this education system should focus their attention on following measures:

- Evaluation system should emphasize equal weight-age for handwriting and subject matter during evaluation.

- Teacher should stress on neat presentation with aesthetic handwriting while preparing students for exams.

- Writing should be considered as way to increase retention power among weak students during remedial teaching.

- Curriculum should help to develop perceptual-sensory motor skills in students.

\section{CONCLUSION}

Study has shown a significant relationship between perception on handwriting and academic achievement which makes us strongly agree the fact that handwriting plays an important role in academic achievement. It has opened a new door to prepare students for high achievements and to inculcate writing habits in them. Teachers' attention seeks here that if a student fail to achieve as expected in spite of strong knowledge base poor handwriting or lack of presentation can be 
considered as a reason for their poor performance. By analyzing male and female perception on handwriting a significant difference is drawn among their perception, female shows a high mean score of perception on handwriting than male. Locality of school has shown no significant difference for students 'perception on handwriting It can thus be concluded that perception of handwriting is not individualized as learning and interest or social background has no role to play in this it fully depends upon the learning environment and undoubtedly on teachers that how much they stress on handwriting for a students' achievement.

\section{REFERENCES}

[1] Abbott, R. and Berninger, V. (2003) Structural equation modeling of relationships among developmental skills and writing skills in primary and intermediate grade writers. Journal of Educational Psychology. Vol 3 478-508.

[2] Case-Smith and Jane. (2011) Effectiveness of an Integrated Handwriting Program for First-Grade Students: A Pilot Study . American Journal of Occupational Therapy. Vol. 65 Issue 6, p670

[3] Christensen and Carol, A. (1999) A. Relationship between automaticity in handwriting and students' ability to generate written text. Journal of Educational Psychology, Vol 91(1), 44-49.

[4] Connelly, V. and Dockrell, J. (2005) The slow handwriting of undergraduate students constrains overall performance in exam essays. Educational Psychology, 25, 99-107.

[5] Graham, S. and Karen, R.(2000) Is handwriting causally related to learning to write? Treatment of handwriting problems in beginning writers. Journal of Educational Psychology, Vol 92(4), 620-633.

[6] Golden, S. A. R. (2011). Problems and Prospectus of Distance Learning, Bharathidhasan University, 343- 344.

[7] Karin, H.J. (2008) Influence of motor stimuli on visual recognition and brain changes . Journal of Educational Psychology, Vol 103(3), 509-522.

[8] Karlo Steinke (2009). Recognition of writers by handwriting images. Pattern Recognition - PR. vol. (14) pp. 357-364.

[9] Longcamp, M. and Pondou, M. (2005) The influence of writing practice on letter recognition in preschool children: A comparison between handwriting \& typing. Acta psychological, 119(1), $67-79$.

[10] Nora, M. and Jessie, P. (2010), Typing compared with handwriting for essay examinations at university Research in Learning Technology, Vol. 18, No. 1. pp. 29-47,

[11] Payne, C. and Fielder (1998) Legibility of doctors' handwriting: quantitative comparative study. Department of Public Health, Vol 317(7162): 863-4.

[12] Stephen, T. and Peverly (2010) The Importance of Handwriting Speed in Adult Writing. Developmental Neuropsychology. Vol 29, 197-216. 